\title{
COMPORTAMENTO TINTORIAL DO MYCOBACTERIUM LEPRAE. REVISÃO HISTÓRICA
}

Luiz Fernando de Góes Siqueira * Regina Gomes de Almeida** Walter Belda*

SIQUEIRA, L. F. de $\boldsymbol{G}$. et al. Comportamento tintorial do Mycobacterium leprae. Revisão histórica. Rev. Saúde públ., S. Paulo, 17:297-315, 1983.

RESUMO: Foi feita revisão histórica sobre os corantes utilizados na identificação do Mycobacterium leprae. Foram analisadas para cada corante, sua composição quimica, propriedades tintoriais e a capacidade de assimilação pelo bacilo nas diversas técnicas de coloração.

UNITERMOS: Mycobacterium leprae. Corantes. Bacilos, coloração.

\section{INTRODUÇAO}

A era cientifica da hanseniase teve inicio com a demonstração, por Hansen, de um bacilo como seu agente etiológico.

Desde então, a identificação da micobactéria é peça importante, fundamentalmente na caracterização dos quadros clínicos que se desenvolvem nos individuos Mitsuda negativos.

Conseqüentemente, há tentativas renovadas no sentido de aprimoramento das técnicas visando melhor e mais fácil visualização do Mycobacterium leprae. Assim se multiplicam os estudos sobre o comportamento tintorial, os fatores de interferencia e como melhor utilizar os corantes existentes.

Em revisão histórica pretendeu-se, nesta primeira comunicação, acompanhar no tempo a utilização dos corantes em função, basica- mente, da capacidade de sua assimilação pelo bacilo de Hansen.

Os anos de pesquisa, neste campo, puseram em evidência um denominador comum ao gênero Mycobacterium: a capacidade de assimilação de substâncias corantes básicas e, menos intensamente, aquelas ácidas possuidoras de, pelo menos, dois grupos auxocrômicos básicos (Campana, 1887; Balthazard, 1907; Rodriguez, 1942; Vegas e Espin, 1943; Ibars, 1949; Lillie, 1965; Delville, 1980).

Tentando uma sistematização que permitisse visão mais abrangente, procuramos não só identificar os corantes utilizados na coloração do Mycobacterium leprae, em termos de suas características quimico-farmacêuticas, desde os precursores até os de atual uso, como reunir a bibliografia especifica sobre a sua aplicação.

* Do Departamento de Epidemiologia da Faculdade de Saúde Pública da Universidade de Såo Paulo - Ar. Dr. Arnaldo, 715 - 01255 - São Paulo, SP - Brasil e do Instituto de Saúde da Secrctaria de Estado da Saúde - Av. Dr. Enéas de Carvalho Aguiar, 188 - 05403 - São Paulo, SP - Brasil.

* Da Divisão de Hansenologia e Dermatologia Sanitária do Instituto de Saúde da Secretaria de Estado da Saúde - Av. Dr. Enéas de Carvalno Asuiar, 188 - $7^{\circ}$ andar - 05403 - São Paulo, SP - Brasil. 
SIQUEIRA, L.F. de G. et al. Comportamento tintorial do Myoobacterium leprae. Revisăo histórica. Rev. Savide públ., S. Paulo, 17:297-315, 1983.

\section{Corantes}

\section{Ácido ósmico}

Classe química: óxido metálico.

Sinonimia: Tetróxido de ósmio, anidrido ósmico ou ácido pirósmico.

Propriedades físico-químicas: Ponto de fusăo $=40^{\circ} \mathrm{C}$.

Características: Cristais dimorfos, incolor ou amarelados. Odor acre análogo ao do cloro. Produtor de vapores venenosos prejudiciais abs olhos, trato respiratório e pele. Possue poder oxidante.

Solubilidade: Solúvel em benzeno, alcool, eter, hidróxido de amônio, oxicloreto de fósforo, água (a $25^{\circ} \mathrm{C}: 7,24 \pm 0,01 \mathrm{~g} / 100 \mathrm{~g}$ ) e tetracloreto de carbono (a $25^{\circ} \mathrm{C}: 375 \pm$ $\pm 17 \mathrm{~g} / 100 \mathrm{~g}$ ) (The Merck Index, 1968).

Fómula estrutural :

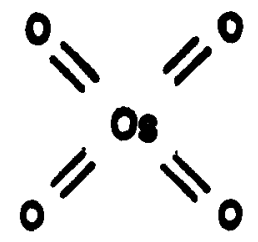

Ao tempo de Hansen o ácido ósmico já era utilizado como fixador e indicador de substâncias gordurosas. Não é um corante mas um óxido instável, que é reduzido a dióxido de ósmio em presença de gorduras insaturadas e ácidos graxos e que são entăo visualizados como massas escuras (Mallory, 1938; Lillie, 1965).

Segundo Ibars (1949), Hansen (1868), estudando cuidadosamente as células, que Virchow (1864) denominara de "Leprazellen" e que já tinham sido descritas por Danielssen e Boeck (1848), viu nelas uns elementos pardos, que suspeitou mais tarde serem corpos bacilares que se tingiam pelo ácido ósmico. As primeiras fotografias dos achados de Hansen, feitas de 1871 a 1873, publicadas por Hansen e Looft (1895) e por Jeanselme (1934), fazem supor que o que foi identificado, inicialmente, foram massas gordurosas coradas.

Na publicação de Hansen e Looft (1895), na descrição do exame a fresco de esmagado de "lepromas", encontramos: "Com lente de maior aumento percebe-se no fluido da preparação, pequenos filamentos indestrutiveis pela potassa. São os bacilos da lepra, pela primeira vez observados no ano de 1871. Se essas preparações forem esmagadas em solução de ácido ósmico ou for 0 nódulo conservado nessa soluçăo, por algumas horas, antes de ser feita a preparaçăo, os filamentos tomarão uma coloração parda e serão observados em maior número nas células".

Posteriormente, autores como Unna, Mantegazza e Joseph, citados por Klingmuller (1930), utilizaram o ácido ósmico em suas preparaçōes.

0 abandono desta substância está ligado ao seu difícil manuseio, toxicidade, custo elevado e, fundamentalmente, ao fato de corar apenas gorduras.

Violeta

\section{Cristal de Violeta}

Classe química: Triarilmetano.

Sinonimia: Cloreto de hexametil pararosanilina, violeta de genciana, violeta de anilina, cloreto de metilrosanilina, violeta de metila $6 \mathrm{~B}$, "brilliant violet 5B", "violet 5BO", "DCS brilliant", "hexamethyl violet" ou "Arizon crystal violet".

Classificação segundo C.I.: Basic Violet 3, C.I. 42.555 .

Caracteristicas: Pó ou cristais brilhantes verde escuro.

Solubilidade: Solúvel em água quente, fria, clorofórmio e etanol. Uma grama se dissolve em cerca de $10 \mathrm{ml}$ de álcool ou em $15 \mathrm{ml}$ de glicerina. Praticamente insolúvel em eter (The Merck Index, 1933; Colour Index, 1971). 
SIQUEIRA, L.F. de G. et al. Comportamento tintorial do Mycobacterium leprae. Revisăo histórica. Rev. Saride públ., S. Paulo, 17:297-315, 1983.

Fórmula estrutural

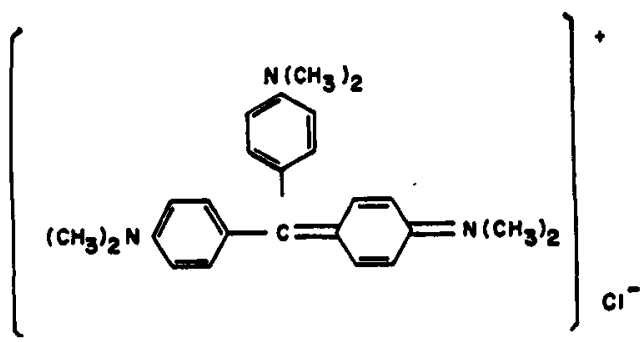

Violeta de Metila

Classe química: Triarilmetano.

Sinonímia: Violeta de genciana, violeta de metila, violeta de anilina, violeta de metila 2B, "methylene violet", "brilliant violet Co", "dahlia B" ou "dahlia violet B".

Classificação segundo C.I.: Basic Violet 1, C.I. 42.535.

Solubilidade: Solúvel em água quente, fria e etanol (Colour Index, 1971).

\section{Violeta de Etila}

Classe quimica: Triarilmetano.

Sinonimia: violeta de etila $\mathrm{AX}$, "ethyl purple 6B" ou "ethyl violet GGA EX".

Classificação segundo C.I.: Basic Violet 4, C.1. 42.600 .

Solubilidade: Solúvel em água quente, fria e etanol (Colour Index, 1971).

Fórmula estrutural:

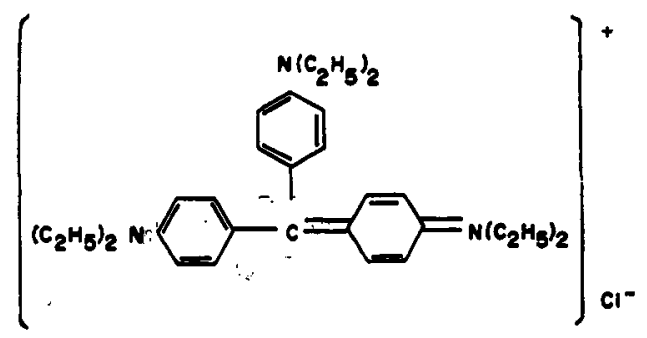

Na forma de cristal de violeta, violeta de metila ou violeta de etila, foi um dos primeiros corantes a serem utilizados. Jeanselme (1934) e Campana (1.894) afirmam ter sido Neisser, em 1879, o primeiro a utilizá-lo com esta indicação, segundo o método de Weigert-Koch. Cornil (1884) considerou-o "corante ideal" para o bacilo de Hansen. Este corante usado em métodos apropriados foi adotado por Hansen (1886) (citado por Rotberg e Bechelli em 1944), Peltier (1891) e por outros (Bertaccin, 1936; Versari, 1923; Wade, 1962a). Encontramos em Loizaga (1936) que Gram aplicara seu método na coloração do bacilo de Hansen, observando então um "envólucro" não corado e grânulos corados no seu interior, não havendo referência a Gram positividade ou Gram negatividade. Lutz (1946), Unna (1891) e Castro (1947), em seus próprios métodos, utilizaram o violeta para estudo dos grânulos, então conhecidos como "coccothrix". Outros métodos foram desenvolvidos baseados no método de Gram, para o estudo das granulações, que passaram a ser conhecidas como granulações de Lutz-Unna (Cerqueira, 1923; Rodriguez e col., 1933; Ibars, 1949). O método de Fontes (1909), associação dos métodos de Ziehl e Gram, até hoje é indicado para tal estudo (Loizaga, 1936; Horta, 1941; Ibars, 1949).

A Gram positividade do bacilo de Hansen vem sendo reafirmada por muitos autores (Pernet, 1903; Emile-Weil, 1905; Campana, 1907; Larouche, 1921; Lesieur e Mouriquand, 1923; Castronuovo, 1936; Amaya, 1947; Cabral, 1947; Wilson, 1947; Ibars, 1949; Yasumoto, 1953; Silva, 1960) como mais uma característica da espécie sem, no entanto, explicitar se a coloração utilizada foi a descrita originalmente por Gram, ou se foi uma de suas variaçōes.

A partir de 1910, inúmeros autores têm demonstrado ser o método de Gram indicado para evidenciar formas não ácido-resistentes do Mycobacterium leprae (Arning e col., 1909; Rodriguez e col., 1933; Fite, 1938; 
SIQUEIRA, L.F. de G. et al. Comportamento tintorial do Mycobacterium leprae. Revisão histórica. Rev. Saúde públ., S. Paulo, 17:297-315, 1983.

Wilson, 1947; Nájera, 1949; Silva Jr., 1949; Portugal e Azulay, 1950; Azulay, 1952; Azulay e Andrade, 1952; Berg, 1953a; Convit e Pinard, 1972; Delville, 1974, 1977, 1980; Harada e col., 1976).

Emile-Weil (1905) e outros autores (Balthazard, 1907; Campana, 1907; Marchoux, 1919; Viola, 1933; Castronuovo, 1936; Amaya, 1947; Lastra, 1950) citam o método de Baumgarten (1884) que, utilizando a violeta, permitiria a diferenciação entre as espécies leprae e tuberculosis.

Atualmente, embora assimilado pelo bacilo, o viøleta não é considerado elemęnto de importância nos métodos de coloraçăo específicos.

Fucsina

\section{Pararosanilina}

Classe química: Triarilmetano.

Sinonímia: Fucsina, parafucsina, paramagenta, rosanilina base, "basic rubin" ou "calcozine magenta $\mathrm{N}$ ".

Classificação segundo C.I.: Basic Red 9, C.I. 42.500 .

Solubilidade: Solúvel em água quente e etanol. Fracamente solúvel em água fria. (Colour Index, 1971).

Fórmula estrutural:

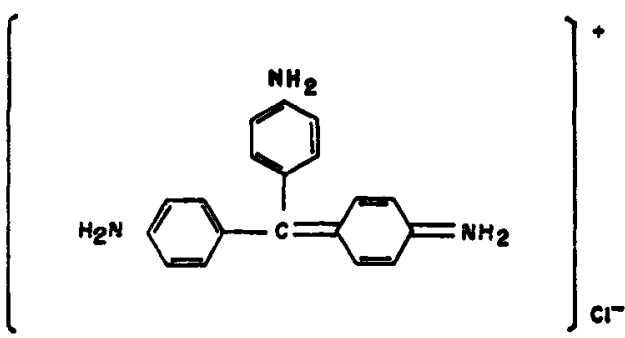

Rosanilina

Classe química: Triarilmetano.

Sinonímia: Fucsina, fucsina básica, cristal de fucsina, magenta, fucsina brilhante, "basic magenta B", "orient basic magenta", "diabasic magenta", "astra fuchsine" ou "rosaniline lake acetate".

Classificação segundo C.I.: Basic Violet 14, C.I. 42.510 .

Solubilidade: Solúvel em água quente, fria e álcool. Praticamente insolúvel em eter. (Colour Index, 1971).

Fórmula estrutural:

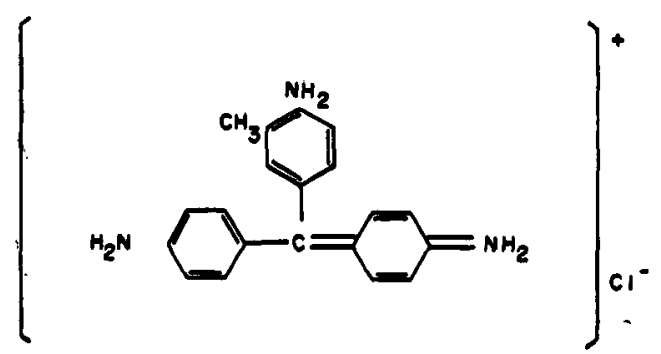

\section{Fucsina Nova}

Classe quimica: Triarilmetano.

Sinonímia: magenta III, nova magenta, "astra new fuchsine", "elcozine magenta" ou "isorubin".

Classificação segundo C.I.: Basic Violet 2, C.1. 42.520 .

Solubilidade: Solúvel em água e álcool. (Colour Index, 1971).

Fórmula estrutural:

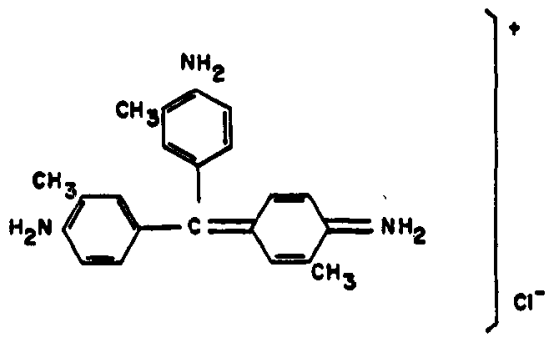


SIQUEIRA, L.F. de G, et al. Comportamento tintorial do Mycobacterium leprae. Revisão histórica. Rev. Saude públ., S. Paulo, 17:297-315, 1983.

Produzindo ótimas colorações, este corante foi inicialmente usado em óleo de anilina segundo a técnica de Ehrlich, citada nos trabalhos de Bezançon (1920) e Mazza e col. (1921). Esta solução em óleo apresentava $o$ inconveniente de ser altamente instável, daí năo poder ser preparada com antecedência. $O$ problema foi eliminado por Ziehl, com a adição de fenol (ou ácido fênico, ou ácido carbólico) à solução. Pouco tempo depois Lubinoff (1888 a, b) afirmava ter aperfeiçoado o método, substituindo o ácido fênico por ácido bórico. Posteriormente, vários pesquisadores estudaram $\mathrm{e}$ deram novas justificativais para o uso do fenol, entre as quais aumentar a solubilidade da fucsina nos lipídeos da parede bacilar (Hanks, 1961b; Lartigue, 1962; Harada, 1976b; Delville, 1980).

Com o uso da fucsina e a introdução do álcool, o método passou a ser conhecido como Ziehl-Neelsen, segundo relata Hallberg (1946). Com o tempo, foi submetido a várias modificações no intuito de melhorar a visualização dos bacilos, porém a fucsina sempre persistiu como corante principal. No início a fucsina não era bem caracterizada. Com o advento da tecnologia dos corantes foram determinadas três classes de fucsina: 1, II, III (Wade, 1952, Harada e col., 1976). Fite (1938) considerou a fucsina III (ou fucsina nova, ou magenta III) como a mais eficiente. Muitos autores passaram também a utilizá-la, obtendo melhores resultados em suas pesquisas (Tilden e Tanaka, 1945; Putt, 1951; Berg, 1953b, Beamer e Firminger, 1955; Wheeler, 1964). Pensa-se hoje que a fucsina utilizada como fucsina básica teria sido uma mistura destas três formas (Harada, 1977; Harada e col., 1976).

O uso alternativo da solução corante a frio, a quente ou a diversas temperaturas (Pachecs e col., 1931; Dubois, 1937; Van Breuseghem e Moules, 1937; Fite, 1933; Inaba, 1938; Wade, 1949; Putt, 1951; Nakamura e col., 1969; Andersen, 1970), a diferentes concentraçōes (Rudel, 1928; Wade, 1928; Lowe, 1934; Brandt e col., 1954; Lillie,
1965) e faixas de $\mathrm{pH}$ (Sato e Mayama, 1950; Fite e Fite, 1965), a tempo de atuação desta (Dubois, 1937; Vieira, 1949; Ogden, 1952), além de outros fatores de interferência (Dharmendra e Mukerjee, 1949; Serial, 1951; Corcos, 1953), foram discutidos em trabalhos com a finalidade de aprimorar 0 método tradicional proporcionando algumas vantagens.

Outros pesquisadores indicaram a adição de novas substâncias para facilitar a assimilação de fucsina (Faraco, 1938; Chabaud, 1942; Castro, 1947; Fite e col., 1947; Blanco e Fite, 1949; Pottz, 1948; Faria, 1949; Kawakami, 1949; Wilkinson, 1951; Fielding 1934; Lowy e col., 1954; Wade, 1957; Hanks, 1961a; Reyes, 1963; Andersen e Chang, 1970; Reich e col., 1972; Harada, 1973, 1976b; Mohysen e Alemayehu, 1973; Periaswami, 1974; Castro e Coelho, 1977; Harada e col., 1976; Harada e Kasai, 1978, a e b; Delville, 1980), como por exemplo os tensio-ativos (Chermock e Muller, 1946; Aubert, 1950; Wade, 1950, 1952; Marti e Johson, 1952; Martinez e Calero, 1946; Chasles, 1961; Ridley e Ridley, 1971). No entanto, com umas poucas modificações, a técnica de Ziehl-Neelsen permanece até hoje como a mais indicada para coloração do Mycobacterium leprae, assim como outros bacilos alcool-ácido resistentes (Pernet, 1901; Fick, 1907; Bard, 1911; Clegg, 1916; Lespinasse, 1919; Zinsser e Russell, 1922; Hasseltine e Gorman, 1924; Argañaraz, 1927; Ohmichi, 1928; Bertrand, 1930; Hoffman, 1933; Lowe, 1934; Carpano, 1936; Dubois, 1937; Van Breuseghem e Moules, 1937; Fite, 1938; Inaba, 1938; Manalang, 1939; Klingmuller, 1930; Fite, 1940; Viola, 1933; Cowdry, 1943; Davison, 1943, Jordan e Burrows, 1943; Maillory, 1938; Torres, 1944; Cowdry, 1940; Montel, 1946a, b; Montel e Giroud 1946; Amaya, 1947; Cabral, 1947; Pardo-Castello c col., 1947; Percival e col., 1947; Zanetti, 1947; Wilson, 1947; Bale, 1948; Bechelli, 1948; Nájera, 1949; Silva Jr., 1949; Marie-Suzanne, 1950; Khanolkar, 1951; 1952; Putt, 1951; Azulay e Andrade, 1952; 
SIQUEIRA, L.F. de G. et al. Comportamento tintorial do Mycobacterium leprae. Revisão histórica. Rev. Sarude puibl., S. Paulo, 17:297-315, 1983.

Beaudiment e Laviron, 1952; Krajian e Gradwohl, 1952; Ramanujam, 1952; Yasumoto, 1953; Azulay e Andrade, 1954; Jopling e Ridley, 1954; Pottz, 1948; Chaterjee e col., 1955; Dubois, 1955; Ishihara e Hagihara, 1954; Jayraj, 1956; Hanks, 1956a, b; Johnston e Lynch, 1957; Rhodes-Jones, 1959; Wade, 1957; Davison, 1960; Ootaka e col., 1959; Silva, 1960; Rees e Valentine, 1962; Serié, 1962; Shepard, 1962; Wade, 1962a, b; Padma, 1963; Lillie, 1965; Wheeler: e col., 1965; Greef e col., 1967; Vestal, 1969; Azulay, 1971; McRae e Shepard, 1971; Reich, 1971; Ridley, 1971; Samuel e Chaterjee, 1971; Periaswami, 1974; Harada, 1976a,b; Harada e col. 1976; Harada e Kasai, 1978; Wheeler e Draper, 1980).

\section{Azul de metileno}

\section{Classe química: Tiazina.}

Sinonímia: Cloreto de 3,9 - bis dimetilamino fenazotianio, cloreto de metiltionina, cloreto de tetrametiltionina ou "Swiss blue".

Classificação segundo C.I.: Basic Blue 9, C.I. 52.015 .

Características: Cristais verde escuro com brilho metálico, sem odor.

Solubilidade: Solúvel em clorofórmio, em água (uma grama se dissolve em cerca de $25 \mathrm{ml}$ de água) e em álcool (uma grama se dissolve em $65 \mathrm{ml}$ de álcool). Insolúvel em eter. (The Mercks Index, 1968; Colour Index, 1971).

Fórmula estrutural:

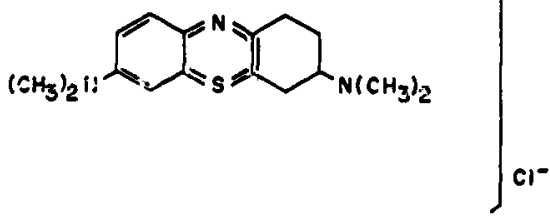

O azul de metileno, em solução aquosa ou alcoólica, é bem assimilado pelo $\mathrm{Myco-}$ bacterium leprae podendo ser usado como corante principal, e assim o foi inicialmente (Unna, 1891; Bosco e Nicastro, 1937; Fite, 1938; Alexander-Jackson, 1945; Lutz, 1946).

Danielssen, citado por Hansen e Looft (1895), empregou empiricamente o azul de metileno na terapêutica da hanseniase. Posteriormente, tendo em vista sua ação antisséptica, vários autores( Lombardo, 1934, 1936, 1937; Prudohome, 1935; Baccareda, 1937; Bosco e Nicastro, 1937; Spada, 1937; Nagao, 1945; Degos e Lotat-Jacob, 1947; Piccardi e Radaeli, 1948; Freitas, 1960) observaram a absorção pelo bacilo, justificando seu uso na terapêutica. Lombardo (1936), embora aceitando a ação corante, questiona a eficácia terapêutica, que foi totalmente rejeitada por Bertaccini (1936) e Nagao (1945). Com estas restrições o produto permaneceu, por algum tempo, como prova diagnóstica "in vivo" das formas baciliferas (Bertaccini, 1936; Lombardo, 1938).

Este procedimento foi abandonado, permánecendo até hoje sua indicação como corante de fundo na baciloscopia da hanseníase.

\section{Azul vitória}

Classe quimica: Triarilmetano.

Sinonímia: "Aizen victoria blue $\mathrm{BH}$ ", "corn blue BN", "fat blue B" ou azul vitória B.

Classificação segundo C.I.: Basic Blue 26, C.I. 44.045 .

Solubilidade: Solúvel em água quente, fria e etanol (Colour Index, 1971).

Fórmula estrutural: 


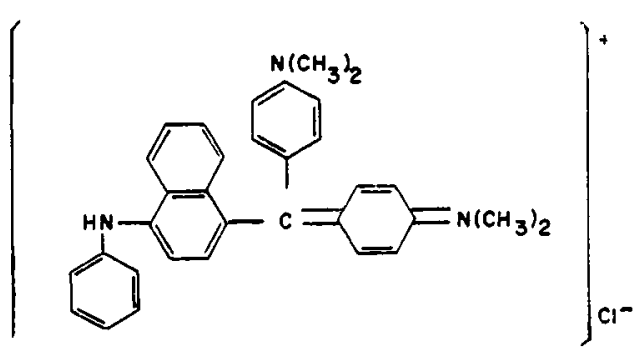

Unna (1910) empregou este corante, em método de dupla coloração, tentando demonstrar as possibilidades de separação do bacilo vivo do bacilo morto. Foi assim un dos precurssores da pesquisa para determinação da viabilidade ou não do bacilo, através de métodos tintoriais. Após longo periodo de esquecimento, esta substância voltou a ser empregada, por alguns autores, como corante principal (Lillie, 1965; Harada, 1976a,c).

\section{Azul noite}

Classe química: Triarilmetano.

Sinonimia: "night blue" ou "nachtblau". Classificação segundo C.I.: Basic Blue 15, C.I. 44.085 .

Solubilidade: Solúvel em água e etanol (Colour Index, 1971).

Fórmula estrutural:

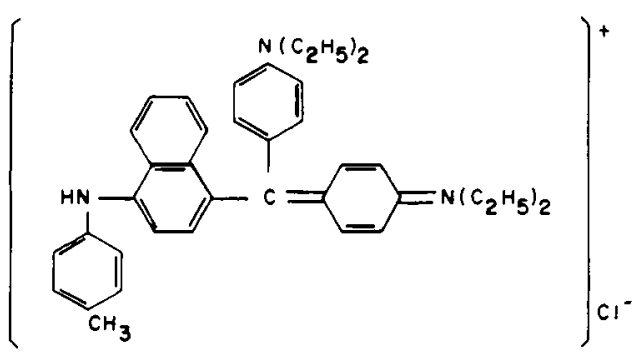

Hallberg (1941) introduziu o azul noite em método próprio para culoração de bacilos álcool-ácido resistentes. Reenstierna, em nota publicada junto ao trabalho de Hallberg (1941), relata o uso deste método pela primeira vez na coloração do $M y$ cobacterium leprae. Hallberg, em 1946, enfatiza sua superioridade na coloração de cortes histológicos de hanseníase com relação ao método de Ziehl-Neelsen.

Curban (1946) chama atenção sobre a excelência deste método na identificação do bacilo de Hansen, assim aceito por outros autores (Pardo-Castello e col. 1947; Ibars, 1949).

\section{Verde malaquita}

Classe química: Triarilmetano.

Sinonimia: Verde anilina, verde da China, verde sólido, "benzaldehyde green", "benzol green", "fast green" ou "light green $\mathrm{N}$ ".

Classificação segundo C.I.: Basic Green :, C.I. 42.000 .

Solubilidade: Solúvel em água quente, fria, etanol, metanol e álcool amílico (Colour Index, 1971).

Fórmula estrutural:

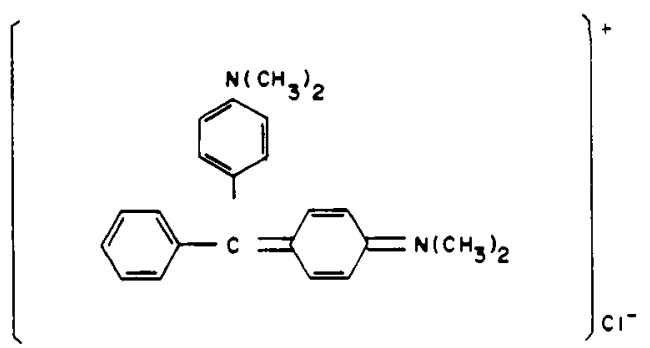

Como todo corante básico, cora bem o Mycobacterium leprae. Biryukova (1967, 1968a,b, 1969), citando Sack (1953), Silver (1956) e Murohashi e col. (1957, 1958, 1960), usou o verde malaquita como corante principal na tentativa de distinguir o bacilo vivo do bacilo morto. Kanetsuna (1964) em seu trabalho também confirmou os achados de Murohashi e col. (1957, 1958) e Murohashi (1960, 1961), 
SIQUERRA, L.F. đe G. et al. Comportamento tintorial do Mycabacterium leprae. Revisão histórica. Rev. Satide publ., S. Paulo, 17:297-315, 1983.

comprovando-os de maior eficiência que o método de distinção de bacilos viáveis proposto por outros autores.

O seu uso como corante de fundo permanece até hoje (Bertrand, 1930; Baccareda, 1937; Fite, 1938; Harada e Kasai, 1978 a).

\section{Nitrato de prata}

Classe química: Sal metálico.

Sinonimia: Nitrato argentico, "piedra infernal" ou azotato de prata.

Características: Cristais incolores transparentes, inodoros e com sabor amargo.

Solubilidade: uma grama se dissolve em $0,4 \mathrm{ml}$ de água, $0,1 \mathrm{ml}$ de água fervente, $30 \mathrm{ml}$ de álcool, $6,5 \mathrm{ml}$ de álcool fervente, $253 \mathrm{ml}$ de acetona. Rapidamente solúvel em água de amônia e lentamente solúvel em eter (The Merck Index, 1968).

Fórmula estrutural:

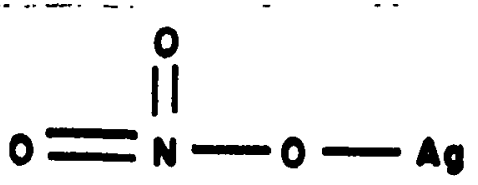

Embora possa agir como tal, esta substância não é um corante. Rodriguez (1942), relatando o método desenvolvido por Unna, a empregou, com sucesso, para identificação de granulações bacilares.

Cunha (1933), Horta (1941) e Ibars (1949) descrevem uma técnica que denominam "Método de Yamamoto", a qual, usando o nitrato de prata como corante principal, propõe um método diferencial entre $M y c o-$ bacterium leprae e Mycobacterium tuberculosis.

Alguns autores (Sutter e Roulet, 1965; Krieg e Meyers, 1979) aplicaram o método de Gomori (1937), fundamentado no nitrato de prata, na identificaçăo do Mycobacterium leprae.
Vegas e Espin (1943), utilizando o nitrato de prata não só como corante, mas também como mordente, em uma combinação de técnicas, observou bons resultados principalmente na identificação de granulações.

Outros métodos baseados na prata foram propostos por vários autores (Blanco e Fite, 1948; Peruchena, 1949; Sanchez, 1953; Balasubrahmanyan e col., 1954), no intuito de evidenciar melhor o bacilo de Hansen.

As dificuldades de seu manuseio e os artefatos de técnica freqüentes, desistimularam a utilização na hansenologia.

\section{Corantes fluorescentes}

\section{Auramina 0}

Classe química: Difenilmetano.

Sinonimia: Amarelo canário, "Pyrktanin", "arizen auramine", "auramine lakeyellow $O$ " ou "calcozine auramine 00 ".

Classificação segundo C.I.: Basic Yellow 2, C.I. 41.000 .

Solubilidade: Solúvel em água quente $\mathrm{e}$ fria (Colour Index, 1971).

Fórmula estrutural:

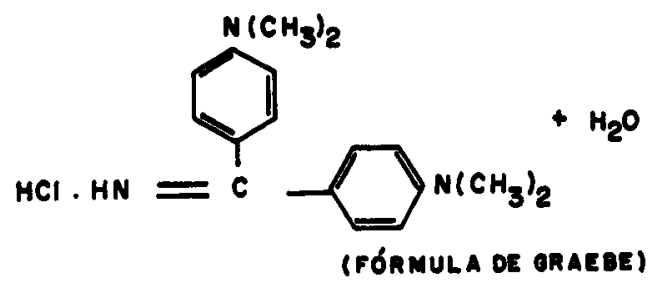

\section{Rodamina B}

Classe quimica: Xanteno.

Sinonímia: Tetraetilrodamina, "Aizen thodamine BH", "acid brilliant pink B" ou "brilliant pink B".

\section{Classificação segundo C.I.: Basic Violet} 10, C.I. 45.170. 
SIQUEIRA, L.F. de G. et al. Comportamento tintorial do Mycobacterium leprae. Revisão histórica. Rev. Saúde públ., S. Paulo, 17:297-315, 1983.

Solubilidade: Solúvel em água e álcool. Fracamente solúvel em acetona e ácido clorídrico (Colour Index, 1971).

Fórmula estrutural:

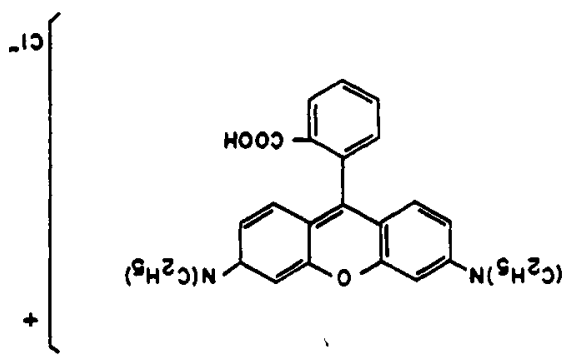

\section{Berberina}

Classe química: Corante básico natural. Sinonimia: "Barberry extract", "Barbery root", "Umbellatine", "Assan Wood", "Dar hald" ou "Dam hald".

Classificação segundo C.I.: Natural Yellow 18, C.I. 75.170.

Características: A berberina básica é instável e assume a forma aldeidica, mas seus sais são derivados da forma amoniacal. Presente em muitas plantas, por exemplo no caule e raízes da Berberis vulgaris.

Solubilidade: Solúvel em água quente (The Merck Index, 1968; Colour Index, 1971).

Fórmula estrutural:

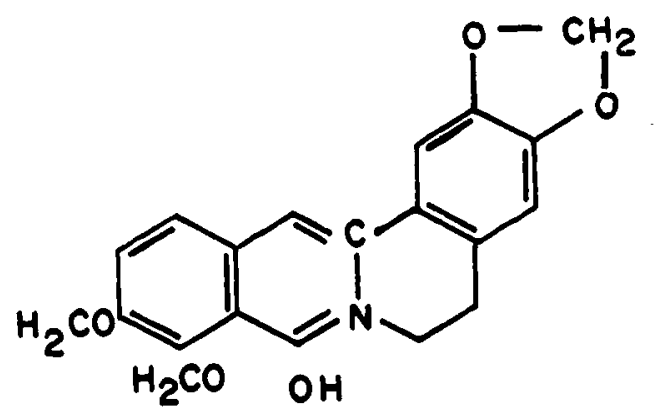

Com o advento da microscopia de fluorescência novos métodos tintoriais foram aplicados ao Mycobacterium leprae. $\mathrm{O}$ bacilo demonstrou boa assimilação quando tratado pela berberina (Henderson e col., 1942; Dubois e Swerts, 1950), auramina O pura (Henderson e col., 1942; Hernandez e col., 1952; Prendes e col. 1953; Shimizu, 1953; Von Haeblert e Murray, 1954; Gilkerson e Kanner, 1963; Koch, 1965; Lillie, 1965; Mansfield, 1970; Ridley e Ridley, 1971; Smithwick e David, 1971; Harada, 1973, 1976c; Delville, 1977, 1980) e auramina O associada à rodamina B (Kuper, 1960; Akers e Morse, 1966; Ridley e Ridley, 1971; Faria, 1974; Jariwala e Kelbar, 1979; Mansfield, 1969; Vestal, 1969).

Dada as dificuldades de sua execução e custo, a microscopia de fluorescência não é empregada, no momento, na rotina de identificação do bacilo de Hansen.

\section{Outros corantes}

Alguns corantes menos usuais têm sido testados na identificação do Mycobacterium leprae. A safranina (C.I. 50.240), nigrosina (C.I. 50.420), "sudan black" (C.I. 26.150), carmin (C.I. 75.470) e "Bismarck brown" (C.I. 21.010), apesar de básicos, não coram o bacilo de Hansen, ou se o fazem é de maneira insatisfatória (Fite, 1938; Burdon, 1946; Jbars, 1949; Chaussinand, 1950; Bermann, 1953; Chaussinand e Viette, 1956; Contreras e col., 1956; Hanks, 1961 a; Fisher e Barksdalle, 1973).

A tionina (C.I. 52.000), o azul de toluidina (C.I. 52.040) e o "eriochrome cyanine R" (Azul Mordente 3 - C.I. 43.820), apesar de corarem metacromaticamente o bacilo, não são de uso prático (Fite, 1938; Zabary-Simon, 1947; Fite, 1960).

Outros corantes básicos foram submetidos a avaliação de seu poder de tingimento, com boa assimilação, como: verde Janus (C.I. 11.045), verde de metila (C.I. 42.590), dália (C.I. 42.530), alaranjado de acridina (C.I. 46.005), amarelo de acridina (C.I. 
SIQUEIRA, L.F. de G. et al. Comportamento tintorial do Mycobacterium leprae. Revisão histórica. Rev. Satude publ., S. Paulo, 17:297-315, 1983.

46.025), azul de Meldola (C.I. 51.175), azul de Nilo (C.I. 51.180), sudan 111 (C.I. 26.100), violeta de ametista (C.I. 50.225) e vermelho neutro (C.I. 50.040) (Fite, 1938; Wenger, 1941; Ibars, 1949; Fite e Fite, 1965; Biryukova, 1969).

O bacilo mostrou-se corado quando submetido ao Giensa, solução de azure Il e eosina), em métodos especiais (Mahdihassan, 1946; Montel, 1946; Aplas, 1965).

O azul de Tripan foi empregado "in vivo" por alguns autores, com resultados contraditórios (Gujo, 1924; Cavazzoni, 1934). Em coloração "in vitro" o azul de Tripan,assim como todos os demais corantes ácidos, não foram assimilados pelo bacilo de Hansen (Fite e Fite, 1965).

Ja com relação aos corantes ácidos possuidores de pelo menos dois grupamentos auxocrômicos básicos, ligados à estrutura principal, testados em relação ao $M y c o b a c-$ terium leprae, somente o "direct green" (C.I. 30.290) e o "Brilliant milling green" (C.I. 42.100) apresentaram resultados positivos. $O$ primeiro cora fortemente e o segundo discretamente (Fite e Fite, 1965).
Inúmeros corantes como: "thioflavin $\mathrm{T}$ " (C.I. 49.005), "phosphine GN" (C.I. 46.045), "acriflavine" (C.I. 46.000), "neutral violet" (C.I. 50.030), "indulin scarlet" (C.I. 50.080), "janus black B" (C.I. 11.825), "chrysoidin Y" (C.I. 11.270), "celestin blue" (C.I. 51.050), "brilliant cresyl blue" (C.I. 51.010), "toluylene blue" (C.I. 49.410), azure A, azure B, azure C, "rhoduline blue $6 G^{\circ}$ " (C.I. 42.025), "pironin Y" (C.I. 45.005), "pironin B" (C.I. 45.010), "pinacyanole" e "methylene green" (C.I. 52.020), embora não testados com relação ao Mycobacterium leprae, evidenciaram coloração satisfatória para outras micobactérias (Fite e Fite, 1965), confirmando 0 antigo conceito de que os corantes básicos são de escolha na identificação de tais bacilos (Campana, 1888; Balthazard, 1907; Rodriguez, 1942; Vegas e Espin, 1943; Ibars, 1949; Lillie, 1965; Deiville, 1980).

Aceita-se hoje que os corantes ácidos, possuidores de pelo menos dois grupos auxocrômicos básicos, também podem ser utilizados em eventuais métodos de coloração do Mycobacterium leprae.

SIQUEIRA, L. F. de G. et al. [Tinctorial behavior of Mycobacterium leprae. A historical review]. Rev. Satide públ., S. Paulo, 17:297-315, 1983.

ABSTRACT: A historical review was made of the dyes utilized to identify the Mycobacterium leprae. The chemical composition and the tinctorial properties of these substances and the dye assimilation capacity of the bacilli were analyzed.

UNITERMS: Mycobacterium leprae. Dyes. Bacillus, stains and staining.

\section{REFGRENCIAS BIBLIOGRAFICAS}

AKERS, W.A. \& MORSE, W.C. Demonstration of $M$. leprae in tissue. Arch. Derm. 94:361-2, 1966.

ALEXANDER-JACKSON, E. Non acid-fast forms as the Mycobacterium of human leprosy. Science, 101:563, 1945.

AMAYA, A.C. Lepra en El Salvador, zonas endemicas y su problema medico-social. El Salvador, 1947. [Tese - Biblioteca Universitária].
ANDERSEN, R.N. \& CHANG, Y.T. Morphologic changes produced by various Ziehl-Neelsen staining technics on Mycobacterium leprae and Mycobacterium lepraemurium. Int. J. Lepr., $38: 344-5,1970$.

APLAS, V. Fine new farberische Nachweismethode fur Mykobakterien im Gewebschnitt. Arch. klin. exp. Derm., 222 :379-82, 1965. 
SIQUEIRA, L.F. de G. et al. Comportamento tintorial do Mycobacterium leprae. Revisão histórica. Rev. Saúde públ., S. Paulo, 17:297-315, 1983.

ARGaFtaRAZ, R. Semiologia y enfermidades de la conjuntiva. Coloration del bacilo de la lepra. Rev. Circ. méd. Argent., 27:1.062-1.112, 1927.

ARNING, E. \& LEWANDOWISKY, F. Uber den Nachweis Ziehl nicht fabbarer Leprabazillen durch Anwendung der prolongierten Gramfarbung nach Much. Dtsch. méd. Woch., 28, 1909. In: Arch. Derm. Shyph., Berlin, 101:431, 1910, [restmo]

AUBERT, E. "Cold" stain for acid-fast bacteria. Canad. J. publ. Flth, 41(1):31, 1950.

AZULAY, R.D. A pesquisa do $M$. leprae pelos métodos de Gram-Weigert e Ziehl em cortes histológicos e pelo método de Ziehl-Gabbet em estregaço. Rev. bras. Leprol., 20(1):22-5, 1952.

AZULAY, R.D. Histopathology of skin lesions in leprosy. Int. J. Lepr., 39:244-56, 1971.

AZULAY, R.D. \& ANDRADE, L.M.C. Indices de positividade bacterioscópica nos tipos histologicos e tuberculoide encontrados na lepra. Rev. bras. Leprol., 20(1):20-1, 1952 .

AZULAY, R.D. \& ANDRADE, L.M.C. Demonstração do $M$. leprae em cortes em 532 casos de lepra. (Estudo comparativo das técnices de Ziehl-Klingmuller e Ziehl-Wade-Klingmuller). In: Congresso Internacional de Lepra, 69, Madri, 1953. Memoria. Madri, 1954. p. 865.

BACCAREDA, A. Alcune osservazione isto-batterioscopiche sui lepromi assumenti in vita il blu di metilene. Boll. Soc. med. chir. Pavia, 51:413-29, 1937.

BALASUBRAHMANYAN, M.; JAYARAJ, A.P. \& GASS, H.H. An improved histological method for examination of cutaneous nerves in leprosy. Lepr. Rev., 25(2):83-6, 1954.

BALE, W.R. The preparation of carbol-fuchsin for Ziehl-Neelsen's stain. Lepr. Rev., $19(4)$ :154, 1948.

BALTHAZARD, V. et al. Précis de pathologie interne. Paris, G. Steinheil-titeus, 1907. v. 1. p. 239.

BARD, L. Examens bacteriologiques. Recherche des microbes par coloration. In: Bard, L. Précis de examens de laboratoire. leme ed. Paris, Masson, 1911, p. 506-10.

BEAMER, P.R. \& FIRMINGER, H.I. Improved method for demonstration acid-fast and spirochetal organisms in histological sections. Lab. Invest., 4:9-17, 1955.
BEAUDIMENT, A. \& LAVIRON. Affections dues aux microbes. La lèpre. In: Beaudiment, A. \& Laviron Medecine tropicale. Geme ed. Paris, Editions Medicales Flammarion, 1952. v. 2, p. 1.405.

BECHELLI, L.M. A importâncie da punçâo ganglionar no asagnóstico da lepra. Arcn. Serv. nac. Lepra, Rio de Janeiru, b(2) :5-yt, 1940.

BERG, J.W. Chemistry of acid-fastness. Proc. soc. exp. Biol., 84:196-8, 1953 a.

BERG, J.W, New method for staining mycobacteria in tissue sections. Arch. Path., $56: 650-2,1953 \mathrm{~b}$.

BERMANN, R. Essais de coloration du bacille de Stefansky et du bacille de Fransen par le noir Soudan B.N. Bull. Acad. Nat. Méd., $137: 295-8,1953$.

BERTACCINI, G. Sulla colorazione vitale dei bacilli della lepra. Boll. Sez. Reg. Milano, $14: 138-40,1936$.

BERTRAND, I. Recherches bactériologiques. In: Bertrand, I. Techniques histologiques de neuropathologie. Paris, Masson, 1930. p. $339-40$.

BEZANÇON, F. Technique générale. Colorations éléctives, In: Benzançon, F. Précis de microbiologie clinique. Beme ed. Paris, Masson, 1920. p. 88.

BIRYUKOVA, S.V. Détermination de la viabilité des mycobactéries de la lèpre à l'aide du procéde cytochimique. Probl. Tuberk., 45(12): 64-7, 1967, In: Trop. Dis. Bull., $65: 769-70,1968$. [resumo]

BIRYUKOVA, S.V. Definition of virulence of human $M$. leprae in pathogenic material by cytochemical methods of staining. Astrakhan. Oblast. Nauch, prakt, Konf. Probl. Tuberck. i Lepry: 146-8, 1968a. In: Int. J. Lepr., 37:327-8, 1969. [resumo]

BIRYUKOVA, S.V. Use of cytochemical methods of staining for determination of the vlabtlity of human leprosy mycobacterial. Astrakhan. Oblast. Nauch. prakt. Konf. Probl. Tuberck. i Lepry: 145-6, 1968b. In: Int. J. Lepr., $37: 327$, 1969. [resumo]

BIRYUKOVA, S.V. Uso del metodo de coloracion citoquimica para la determinacion de la viabilidade de las micobactérias de la lepra humana. Vop. Lepr. Derm., 6(22). 1969. In: Leprologia, 15(2):90, 1970. [resumo] 
SIQUEIRA, L.F. de G. et al. Comportamento tintorial do Mycobacterium leprae. Revisão histórica. Rev. Saúde públ., S. Paulo, 17:297-315, 1983.

BLANCO, F.L. \& FITE, G.L. Silverıng of lepra bacilit in tissues. Arch. Pach, $\pm 6: b 4 z-y$, 1 1948.

BLANCO, F.L. \& FITE, G.L. The effect of Ilxatives on the staining procedures for lepra bacilli. In: Congresso Internacional de la Lepra, 5o, Habana, 1958. Memoria. Habana, 1949, p. 571.

BOSCO, I, \& NICASTRO, A. Su alcune proprieta tintorialli e cromopessiche dei bacilli di Hansen un vivu ed in vitro. Arch. ital. Lerm., 13:565-72, 1937.

BRANDT, F.A. \& LLOYD, D.L. Differential staining for $M$. tuberculosis and $M$. leprae; a modification of the Liehl-areeisen stall, Lao. Invest., $\mathbf{3}: 296-302,1954$.

BURDON, K.L. Disparity in appearance of the Hansen's bacille - "When staned for fat". J. Bact., 52:67y-80, 1946

CABRAL, G. Lepra. Afr. méd., 13:73-9, 1947.

CAMPANA, R. Alcune particolarità đi distribuizione, mortologia et colorazione del vacillo della lepra. Gazz. degli ospitali, 63, 1887, In: Arch. Derm. Syph., Berlin, $20: 248,1888$.

CAMPANA, R. Propritá del bacilo leproso in rapporto colle sostanze coloranti ed alcline reagenti. In: Campana, $R$. Lepra, Genova, Tipografia del Istituto Sordo-Muti, 1894. p. 108.

CAMPANA, R. Lepra, $3^{a}$ ed. Torino. Unione Tipográfico-Editrice Torinese, 1907.

CARPANO, M. New stain for the lepra bacillus. Arch. ital. Anat. Istol. pat., 1, 1936. In: Urol. cutan. Rev. (Chic.), 41(3):225, 1937. [resumo]

CASTRO, G.M.O. Staining nodules of the leprosy bacillus. Lepr. Rev. $18(2 / 3): 45-9,1947$.

CASTRO, I.M. \& COELHO, J.C. Coloração do Mycobacterium leprae e texturas nos cortes de parafina (método original). Bol. Div. nac, Derm., 37(2/4):43-5, 1977.

CASTRonuovo, G. Bacillo della lebbra o di Hansen. In: Castronuovo, G. Malattie tropicali. Napoli, Libr. V. Idelson, 1936. p. 656.

CAVAzzoNI, L.Z. E possivel corar os bacilos da lepra in vivo. Arch. Biol., S. Paulo, 16(181)::991, 1934 .
CERQUEIRA, D. Sobre a coloração do bacilo de Hansen. Ann. Frac. Med. Rio de Janeiro, $7: 102-8,1923$.

CHABAUD, A. Altération du bacille de Hansen par les fixateurs. Role protecteur de l'ácide phénique. Ann. Inst. Pasteur, $68: 106-13,1942$.

CHASLES, P. New simple method for staining Hansen bacillus (A modification of Ziehl-Neelsen method). In: National Leprosy Conference of Ethiopia, 2nd, Addis-Ababa, 1961. Report. Adüis-Ababa, 1962. p. 80-3.

CHATTERJEE, K.R.; DASGUPTA, N.N. \& DE, M.L. Observations on the morphology of Mycobacterium leprae by ordinary optics, phase microscopy, and electron microscopy. Int. J. Lepr., 23:385-92, 1955.

CHAUSSINAND, R. Apêndice. In: Chaussinand, R. La lepre. Paris, L'Expansion Scientifique Française, 1950. p. 177-81.

CHAUSSINAND, R. \& VIETTE, M. Etude de la coloration des bacilles ácido-alcool-resistantes par le noir Soudan. Ann. Inst. Pasteur, 89:280-9, 1955. In: Int. J. Lepr., $24: 123,1956$. [resumo]

CHERMOCK, R.L. \& MULLER, H.E. Use of wetting agents in histological fixatives. Science, 103:731-2, 1946.

CLEGG, M.T. The cultivation of a nonchromogenic acid-fast bacillus from a case of nodular leprosy. Publ. Flth Bull., Washington, $75: 23-5,1916$.

COLOUR Index, 3rd ed. Yorkshire, Society of Dyers and Colourists, 1971.

CONTRERAS, F.; GUILLEN, J.; TARABINI, J. \& TERENCIO, J. La diferenciacion del bacilo de Hansen $y$ de Koch mediante 1a tincion con el negro Sudan. Acta dermo-Sifilogr., Madrid, 47:475-80, 1956.

CONVIT, J. \& PINARD, M.E. A simple method for the differentiation of Mycobacterium leprae from other mycobacteria through routine staining technics. Int. J. Lepr., 40:130-2, 1972.

CORCOS, M.G. Human lepra bacilli exposed to sunlight will retain their acid-fastness if they are first heated. Lepr. Rev., $24: 165-69,1953$. 
SIQUEIRA, L.F. de G. et al. Comportamento tintorial do Mycobacterium leprae. Revisão histórica. Rev. Saúde públ., S. Paulo, 17:297-315, 1983.

CORNIL, M. Leçons professés pendant le premier semestre de l'anné (1883-1884). In: Cornil, M. Lèpre ou elephantiasis des Grecs. Paris, Ancienne Libraire Germe Baillière et C. Felix Alcan, 1884.

COWDRY, E.V. Cytological studies on globi in leprosy. Amer. J. Path., 16:103-136, 1940.

COWDRY, E.V. Techniques: Leprosy baciili. In: Cowdry, E.V. Microscopic technique in biology and medicine. Baltimore, Willians \& Wilkins, 1943. p. 106.

CUNHA, R.A. Lepra. In: Cunha, R.A. Cursos de extensão universitória. Licōes de microbiologia (Setembro a novembro de 1932). Belo Horizonte, Imprensa oficial de Minas Gerais, 1933. p. 27-42.

CURBAN, G.V. Estudo morfologico e quantitativo do método de Hallberg na coloração do bacilo da lepra. Rev. Inst. Adolfo Lutz, S. Paulo, 6:50-63, 1946.

DAVISON, A.R. Descolorizing of Mycobacterium leprae. Int. J. Lepr., 11(Sp.n.):49-51, 1943.

DAVISON, A.R. The techique of staining leprosy bacilli in smears. Lepr. Rev., 31:305-7, 1960.

DEGOS, R. \& LORTAT-JACOB, E. Chapitre I: Taches Dyschromies, In: Degos, R. \& Lortat-Jacob, E. La dermatologie. Senie ed. Paris, Librairie Maloine, 1947. p. 61.

DELVILLE, J. Microbiologie de la lèpre. Comportament et affinites tinctoriales du bacille de Hansen dans les lesions lepreuses. Ann. Soc. belge MEd. trop., 54:457-62, 1974.

DELVILle, J. Acido-alcoolo résistance de $\boldsymbol{M}$. leprae et valeur relative des divers procédés de coloration. Acta Leprol., $N$. S., $(66 / 67): 265-70,1977$.

DELVILLE, J. Acido-alcoolo résistance de $M$. leprae importance de la technique de coloration dans le diagnostic microbiologique de la lèpre. Acta Lepro., N.S. (78) :11-17, 1980.

DHARMENDRA \& MUKERJEE, N. Effect of sunlight on the staining properties of the leprosy bacillus. In: Congresso Internacional de La Lepra, 5\%, Habana, 1948. Memoria. Habana, 1949. p. 571.

DUBOIS, A. La demonstration du bacille de Hansen dans les coupes histologiques. Ann. Soc. belge Méd. trop., 17:291-6, 1937
DUBOIs, A. Technique de la coloration du bacille de Hansen. In: Dubois, A. La lepre: diagnostic et traitement. Anvers, La Foberda et Le Foreami, 1955. p. 59.

DUBOIS, A. \& SWERTS, L. L'emploi du microscope à fluorescence dans le diagnostic de la lèpre. Ann. Soc. belge Méd. trop., 30:1.473-5, 1950.

EMILE-WEIL, M.P. Les réactions colorantes du bacille de la lèpre. C.R. Soc. Biol., Paris, 58:977-8, 1905.

FARACO, J. Bacillos de Hansen e cortes de parafina. Methodo complementar para a pesquiza de bacillos de Hansen em cortes de material incluido em parafina. Rev. bras. Leprol., 6(2):177-80, 1938.

FARIA, J.L. Valor do método de Faraco para coloração do bacilo de Hansen em cortes. Rev. bras. Leprol., 17(1):18-26, 1949.

FARIA, L.L. Fluorescent staining for Mycobacterium leprae in tissue sections comparison with Fite-Faraco procedure. Int. J. Lepr., 42:52-4, 1974.

FICK, J. Zu Farbung der leprabazlllen en Drineu Hewbsschnitten. Petersburger med. Wehschr., 27, 1907. In: Bibl. Inter. lepra, 7(4):236, 1908. [resumo]

FIELDING, J.W. Staining acid-fast bacilli; the effects of fixatives and $\mathrm{H}$-ion concentration on acid-fastness. Aust. $J$. exp. Biol. med. Sci., 12, 1934. In: Lepr. Rev., $11(3): 150-1,1940$ [resumo]

FISHER, C.A. \& BARKSDALE, L. Cytochemical reactions of human leprosy bacilli and mycobacteria: ultrastructural implications. J. Bact., 113:1.389-99, 1973.

FITE, G.L. The staining of acid fast bacilli in paraffin sections. Amer. J. Path., 14:491$-507,1938$

FITE, G.L. The fuchsin-formaldehyde method of staining acid-fast bacilli in paraffin sections. J. Lab. Clin. Med., 25:743-4. 1940. In: Int. J. Lepr., 9:264, 1941. [resumo]

FITE, G.L. Metachromasic of mycobacterla. Amer. Rev, resp. Dis., 82:574-6, 1960.

FITE, G.L.; CAMBRE, P.J. \& TURNER, M.H Procedure for demonstrating lepra bacilli in paraffin sections. Arch, Path., $43: 624-5$, 1947. 
SIQUEIRA, L.F. de G. et al. Comportamento tintorial do Mycobacterium leprae. Revisão histórica. Rev. Saride publ., S. Paulo, 17:297-315, 1983.

FITE, G.L. \& FITE, C.W. Dye adsorption by mycobacteria. Int. J. Lepr., $33: 324-41$, 1965.

FONTES, A. Estudos sobre a tuberculose. Mem Inst. Oswaldo Cruz, 1:51-68, 1909.

FREITAS, V. A prova do azul de metileno na lepra. Arch. mim. Leprol., 20:470-84, 1960.

GILKERSON, S.W. \& KANNER, O. Improved technique for the detection of acid-fast bacill by fluorescence. $J$. Bact., $86: 890-1$. 1963.

GOMORI. G. Silver impregnation of reticulum in paraffin sections. Amer. J. Path. 13:993-1001, 1937.

GREEF, E.F.; LATERZA, A.M. \& SERIAL, A. El empleo del metodo de Ziehl-Neelsen para la coloracion del Mycobacterium leprae. Leprologia, $12: 124-30$, 1967.

GUJO, K. Leprabazillen und vitale farbung. Tokyo Jj. Shsh., p. 795-802, 1921. In: Trop. Dis. Bull., 21:185, 1924. [resumo]

HALLBERG, V. A new method for staining tubercle baclll (with a note by J. Reenstierna on the use of this method for staining leprosy bacilli). Acta med. Scand., 108:11-7, 1941. In:Int. J. Lepr., $13: 179,1945$. [restmo]

HALLBERG, V. A new method for staining tubercle bacilli aplicable also to the micro-organism of leprosy and other acid-fast germs. Upsala, Sweden, Almqvist \& Wiksells Boktryckeri Ab, 1946.

HANKS, J.H. Retention and differentiation of carbol-fuchsin stained mycobacteria in diagnostic fllms. Amer. Rev. Tuberc., $74: 597-607$, 1956 a.

FANKS, J.H. Retention and differentiation of mycobacteria in tissue sections. Amer. Rev. Tuberc., 74:608-15, 1956b.

HANKS, J.H. The problem of preserving internal structures in pathogenic mycobacteria by conventional methods in fixafion. Int. J. Lepr., 29:175-8, 1961 a.

HANKS, J.H. Demonstration of capsules on $M$. leprae during carbol-fuchsin staining mechanism of the ZiehI-Neelsen stain. Inst. J. Lepr., 29:179-82, 1961 b.

HANSEN. G.A. \& LOOFT, C. Leprosy: in its clinical \& pathological aspects. Bristol, John Wright, 1895.
HARADA, $K$. Effect of prior oxidation on the acid-fastness of mycobacteria. Stain Technol., 28:269-73, 1973.

HARADA, K. The use of non-deparaffinized tissue sections for staining leprosy bacllli. Int. $J$. Lepr, 44:366-8, 1976a.

HARADA, K. Staining mycobacteria with periodic acid-carbol pararosaniline stain: its principle and practice. Int. J. Lepr., $44: 543,1976$ b.

HARADA, $\mathrm{K}$. The nature of mycobacterial acid-fastness. Stain Technol., 51:255-60, $1976 \mathrm{c}$.

HARADA, K. A modified allochrome procedure for demonstrating mycobacteria in tissue sections. Int. J. Lepr., 45:49-51, 1977.

HARADA, K. ; GIDOH, S. \& TSUTSUMI, S. Staining mycobacteria with carbolfuchsin: properties of solutions prepared with different samples of basic fuchsin. Microscop. Acta, 78:21-7, 1976.

HARADA, K. \& KASAI, T. Two methods of demonstrating leprosy bacllli in smears. Int. J. Lepr., 46:167-71, 1978 a.

HARADA, K. \& KASAI, T. Application of periodic acid-carbol pararosanilin stain and periodic acid-methanamine silver stain for staining leprosy bacllli in leprous stain lesions. In: Int. J. Lepr., 47 (suppl. 2):366-7, 1979. [resumo] (Apresentado no XI Congresso Internacional de Leprologia, México, 1978 b).

HASSELTINE, H.E. \& GORMAN, P.J. A comparative study of the Schulte-Tigges and the Ziehl-Neelsen method of staining $M$. leprae. Publ. Hlth Rep., 39:2.683-5, 1924.

HENDERSON, J.A.; SPAULDING, E.H. \& GAULT, E.S. Demonstration of globi and leprosy bacilli by fluorescence $\mathrm{mi}$ croscopy. Proc. Soc. exp. Biol., 50:91-2, 1942.

HERNANDEZ, A.C.; PRENDS, M.A.G. \& CARBONELL, A.F. La baclloscopia fluorescente en la lepra tuberculódde. Rev. Sif. Leprol., Cuba, 8(2):26-7, 1952.

HOFFMAN, W.H. The granular forms of the leprosy bacillus. Int. J. Lepr., 1:149-58, 1933.

HORTA, A.C. Diagnóstico clinico, laboratorial $e$ imunobiológico. Rio de Janeiro, Serviço Nacional de LepräImprensa Nacional, 1941. 
SIQUEIRA, L.F. de G. et al. Comportamento tintorial do Mycobacterium leprae. Revisáo histórica. Rev. Saúde puibl., S. Paulo, 17:297-315, 1983.

IBARS, D.A. Tecnicas de coloracion del Mycobacterium leprae. Fontilles, Alicante, 2:231-6, 1949.

INABA, T. Ueber den Entfarbungsvorgang der leprabazillen in gewebe. $L a$ Lepro, 9:43-65, 1938.

ISHIHARA, S. \& HAGIHARA, S. Study on the procedure for demonstrating lepra bacilli in paraffin sections. La Lepro, 23:143-6, 1954.

JARIWALA, H.J. \& KELKAR, S.S. Fluorescence microscopy for detection of $M$. leprae in tissue sections. Int. J. Lepr., $47: 33-6$, 1979.

JAYRAJ, P. Periodic acid in the staining of acid-fast bacilli in tissue sections. Lepr. Indian, 28(2):61, 1956.

JEANSELME, E. La Lèpre. Paris, G. Doin, 1934.

JOHNSTON, D.G. \& LYNCH, H.P. Combination stain for acid-fast bacilli and fungi. Lab. Invest., 6:187-90, 1957.

JOPLING, W.H. \& RIDLEY, M.J. Isoniazid in lepromatous leprosy. Trans. roy. Soc. trop. Med. Hyg., 48(2):132-8, 1954.

JORDAN, E.O. \& BURROWS, W. The bacillus of leprosy (Mycobacterium leprae) Morphology and staining. In: Jordan, E.O. Burrows, W. Textbook of bacteriology. Philadelphia, Saunders, 1943. p. 504.

KANETSUNA, F. A study of malachite green staining of leprosy bacilli. Int. J. Lepr., $32: 185-94,1964$.

KAWAKAMI, I. The fuchsin buffer staining of acid-fast bacterium tissue. La Lepro, $18: 56,1949$.

KHANOLKAR, V.R. Method of taking biopsy tissue for histological examination. Lepr. Rev., 22(3/4):83-5, 1951.

KHANOLKAR, V.R. A concentration method for acid-fast bacilli in skin blopsies from leprosy patients. Lepr. Rev., 23(3/4):133$-4,1952$.

KLINGMULLER, V. Farbungen des Leprabacillus. In: Klingmuller, V. Die Lepra. Berlin, Jadassohn, Josef, J. Springer, 1930. v. 10. p. 90-4.

KLINGMULLER, V. Staining baclli in sections. Int. J. Lepr., 8:368-9, 1940.
KOCH, M.L. Comparison of fluorescence microscopy with Ziehl-Neelsen stain for demostration of acid-fast bacilli in smear preparations and tissue sections. Amer. Rev. resp. Dis., 91:283, 1965.

KRAJIAN, A.A. \& GRADWOHL, R.B.H. Histopatological technic. 2nd ed. St. Louls, Mosby, 1952.

KRIEG, R.E. \& MEYERS, W.M. Demonstration of $M$. leprae in tissue from bacteriologically negative treated leproumatous leprosy patients. In: Int. J. Lepr., 47 (supl. 2):367, 1979. [resumo] (Apresentado no XI Congresso Internacional de Leprologia, Mexico, 1978).

KUPER, S.W. \& MAY, J.R. Detection of acid-fast organisms in tissue sections by fluorescence microscopy. J. Path. Bact., $79: 59-68,1960$.

LAROUCHE, G. Examens de laboratoire du médecin praticien. 2eme ed. Paris, Masson, 1921.

LARTIGUE, O.J. \& FITE, G.L. The chemistry of the acid-fast reaction. $J$. Histochem. Cytochem., 10:611-8, 1962.

LASTRA, J.M. Bacteriologia de la infeccion leprosa. Frontilles, Alicante, z:367-74, 1950.

LESIEUR, C. \& MOURIQUAND, G. Diagnostic par les méthodes de laboratoire au lit du malade. Paris, Baillière, 1923.

LESPINASSE, Sur l'application de la méthode Cépède a la coloration du bacille de la lèpre. O. R. Acad. Sciences, $167: 702,1918$. In: Bull. Inst. Pasteur, 17(1):27, 1919. [resumo]

LILIIE, R.D. Acid-fast stains. In: Lillie, R.D. Histopathological technic and practical histochemistry. 3rd ed. London, McGraw-Hill 1965. p. 575-81.

LOIZAGA, D. Bacillos de Hansen y outros ácido-resistentes aislados de lesiones leprosas coloreados por el metodo de Fontes. Rev. argent. Dermatosif., 20:261-5, 1936.

LOMBARDO, C. UIteriore richerce sulla colorazione in vivo dei bacilli della lepra. Boll. Sez. Reg. Milano, 4:344-47, 1934.

LOMBARDO, C. Nuova indagini sulla colorabilitá "In vivo" del bacilli della lepra e della tubercuiosi. Boll. Sez. Reg. Milano, 1:121-3, 1936. 
SIQUEIRA, L.F, de G, et al. Comportamento tintorial do Mycobacterium leprae. Revisão histórica. Rev. Saúde públ., S. Paulo, 17:297-315, 1983.

LOMBARDO, C. Dimonstrazione di preparati microscopici sulla colorazione in vivo col blu di metilene dei bacilli della lepra. Boll. Sez. Reg. Brescia, 3:332, 1937.

LOMBARDO, C. Sulla colorazione "in vivo" dei bacilli della lepra. Int. J. Leprr., 6(3):466, 1938.

LOWE, J. A note on the staining of Mycobacterium leprae in tissue sections. Ind. J. med. Res., $22: 313-15,1934$.

LOWY, L. \& RIDLEY, D.S. The acid-fast staining properties of Mycobacterium leprae. Trans. roy. Soc. trop. Med. Hyg., 48:406-10, 1954.

LUBINOFF, M. Borofuchsin zum farben von leprabacillen. Mh. prafet. Derm., $\mathbf{7}(16)$ : 801,1888 a.

LUBINOFF, M. Sul la technique de la coloration des bacilles de la tuberculose et de la lepre. Zbl. Bakt. Parist. 3:540, 1888 b. In: Ann. Inst. Pasteur, 2(5): 289. 1888 [resumo]

LUTZ, A. Relatório do Hospital dos Lazaros do Rio de Janeiro, 1887. In: Souza-Araújo, H.C. História da Lepra no Brasil. Periodos coloniais e monárquicos (1500-1888). Rio de Janeiro, Imprensa Nacional, 1946, v. 1, p. 491

MAHDIHASSAN, $\mathbf{S}$. The carbohydrate-lipoid envelop of the leprosy germ. Currente Sc. Bangalores, $15-49,1946$. In: Quart. Rev. Derm. Syph., 1(2):185, 1946. [resumo]

MALLORY, F.B. Pathological technique. Philadelphia, Saunders, 1938.

MANALANG, J. A comparison of the cooper modification and the culion modification of the Ziehl-Neelsen stajning method for "Myco. leprae". Mth. Bull. Bur. Ht!th Philipp., 19:287-92, 1939.

MANSFIELD, R.E. Fluorochrome staining if Mycobacterium leprae. In: Leprosy Symposium, San Francisco, 1969. In: Int. J. Lepr., 37:456, 1969. [resumo]

MANSFIELD, R.E. An improved method for the fluorochrome staining of mycobacteria in tissue and smears. Amer. $J$. clin. Path., 53:394-406, 1970.

MARCHOUX. E. Le bacille de Hansen. Coloration des germs. In: Marchoux, E. Traite de patologie exotique, clinique et terapeutique. Paris, Baillière, 1919. v. 7 , p. 350 .
MARIE-SUZANNE, Soe: $r$ \& RABILLOUD, $\mathbf{B}$. Technique de coloration combinée du bacille de Hansen sur les coupes histulogiques. Bull. Histol. Techn. micr., 27:39, 1950, In: Int. J. Lepr., 18:441, 1950. [resumo]

MARTI. W.J. \& JOHSON, B.H. Acid-tast staining technic for histologic studies. Am. Soc. clin. Path. Techn. Bull., 21:41, 1951. In: Int. J. Lepr., 20:413, 1952. [resumo]

MARTINEZ, B.L. \& CALERO, J.R. Nuevos métodos de coloracion del bacilo de Hansen con fucsina tensio-activas $A$.ct. dermo-sifiliogr., Madrid, 47:46j- $\delta, 1956$.

MAZZA, S. \& NINI, F.L, La sulfito-resisténcia de los bacilos de Koch $y$ Hansen $y$ el nuevo procedimiento de Konrich para clorear-los. Pren. med. argent, 7(25):227, 1921.

McRAE, D.H. \& SHEPARD, C.C. Relationshyp between the staining quality of $M y c o-$ bacterium leprae and infectivity for mice. Infect. Immun., 3:116-20, 1971.

THE MERCK INDEX, 8th ed. Rahway, N.J., Merck \& Co. Inc., 1968.

MOHYSEN, A.M. \& ALEMAYEHU, W. Appl1cation of Nyka's method for the staining of mycobacteria in leprous skin sections. Acta path. microbiol. scand. (A), 81:71-4, 1973.

MONTEL. R. Aspects différents du bacille de Hansen dans le sang de leproma coloré par le méthođe de Macchiavello. Bull. Soc. Path. exot., 39:167-70, 1946 a.

MONTEL, R. Bacillemie lepreuse - Affinités tintoriales du bacille de Hansen. Bull. Acad. Méd., 130:165-8, 1946 b. In: Trop. Dis. Bull., 43(12:1.152, 1946. [resumo]

MONTEL, R. \& GIROUD, P. Affinités tintoriales du bacille de Stefansky. (Méthode de Macchiavello). Bull. Soc. Path. exot., $39: 248-50,1946$.

NAGAO, S. Action du bleu de methylène sur le Mycobacterium leprae. Int. J. Lepr., $13: 165$, 1945. [resumo]

N.A.JERA, L. Sobre la investigacion negativa de bacilos ácidos-resistentes en el exudato nasal de enfermos. Arch. mineir. Leprol. 9(1):17-22, 1949. 
SIQUEIRA, L.F. de G. et al. Comportamento tintorial do Mycobacterium leprae. Revisăo histórica. Rev. Sarode puibl., S. Paulo, 17:297-315, 1983.

NAKAMURA, M.; TSCHUIZA, T.; NAGAMATSU, T.; AONO, Y. \& ISHIDA, M. Staining conditions influencing morphological index of acid-fast bacilli. Kurume Med. $J .$, 15(1) :39-41, 1968. In: Int. J. Lepr., 37:434, 1969. [resumo]

OGDEN, M.A. Diagnosis of leprosy. J. Amer. med. Ass., 150:814, 1952.

OHMICHI, N. Differenzierude farbung der baurefesten bacillen. Okayama Jgakwai Zasshi, 40:1.747-64, 1928. In: Zbl. Haut. -u. Geschl.-Kr., 31(1/2):40, 1929. [resumo]

OOTAKA, K.; SATOO, S.; SATOO, J. et al. Une nouvelle coloration diferentielle entre les bacilles de la tuberculose et les bacilles de la lèpre. Hirosak Med. $J$, $10: 237$, 1959. In: Int. J. Lepr., 28:210, 1960.

PACHECO, G.; MACIEL, J. \& PENHA, A. Sobre a coloraçáo dos bacilos achroresistentes. Brasil méd.., 45:1.042, 1931.

PADMA, M.N. A standard technique of acidfast staining for $M$. leprae in smears. Lepr. India, 35(2) :62-4, 1963.

PARDO-CASTELLO, V.; TIANT, F.R. \& PINEYRO, R. Never lesions of leprosy. Arch. Derm. Syph., Chicago, 55:783-97. 194i.

PELTIER, A. De la lèpre en Nouvelle Caledonia. Paris, 1891. [Tese].

PERCIVAL, G.H.; DRENNAN, A.M. \& DODDS, T.C. Granulomatous conditions: leprosy. In: Percival, G.H.; Drennan, A.M. \& Dodds, T.C. Atlas of histopathology of the skin. Edinburgh, E. \& S. Livingstone, 1947. p. 251 .

PERIASWAMI, V. A modifled technique for staining paraffin sections for acid-fast bacilli. Lepr. India, 46(2):94-8, 1974.

PERNET, G. Microscopical preparations. Trans, derm. Soc. G.B.I., 7:47-8, 1901.

PERNET, G. Diseases of the skin. 3rd ed. London, H.K. Lewes, 1903, v, 2, n. 2. p. 1329 .

PERUChENA, J.G. Processo apropriado para a Impregnação do Mycobacterium leprae. Rev. Quim. Farm. Rio de Janeiro, 14(4) :43-4, 1949.
PICCARDI, G. \& RADAELI, G. Sulla ricerca e sul comportamento del composti di molobidemo negli ogani leprosy. Spectroch. Acta, 43(2):233-4, 1948. In: Trop. Dis. Bull., 45:1.092, 1948. [resumo]

PORTUGAL, H. \& AZULAY, R.D. Vantagens de coloração pelo método de Gram-Weigert dos cortes de lesóes lepromatosas. Rev. bras Leprol., 18:206-7, 1950.

POTTZ, G.E. A simplified procedure for staining acid-fast bacteria in smears and tissue sections. Bull. Internat. Assoc. Med. Mus., 28:188-91, 1948. In: Int. J. Lepr., $22: 244$, 1948. [resumo]

PRENDES, M.A.G.; CARBONELL, A.F.; PARDO-CASTELLO, V. \& HERNANDEZ, A.C. La microscopia fluorescente en leprologia - Valoracion del metodo fluorescente frente al Ziehl-Neelsen, en el diagnóstico bacteriológico. Int. J. Lepr., 21:35-40, 1958.

PRUDOHOME, R.O Fixation "In vivo" du blue de methylène par les bacilles lepreux. C.R. Soc. Biol., Paris, 119:1.326, 1935.

PUTT, F.A. A modified Ziehl-Neelsen method for demonstration of leprosy bacilli and other acid-fast organisms, Amer. J. clin. Path., 21:92-5, 1951.

RAMANUJAM, $\mathbf{K}$. Bacterlological examination in leprosy. Lepr. Rev., 23:127-32, 1952.

REES, R.J.W. \& ALENTINE, R.C. The appearance of dead leprosy bacilli by light and electron microscopy. Int. J. Lepr., $30: 1-9,1962$.

REICH, C.V. A comparison of the growth curves of the NQ bacillus (Mycobacterium sp) derived by photometric turbity, microscopy counting and viability in a tube - diluition - series Int. J. Lepr., $39: 25-33,1971$.

REICH, C.V.; ABALOS, R. \& MADARANG, M. A quantitative comparison of standard Zlehl-Neelsen v.s. Nyka (periodate treated) stained smears from leprosy patients. Int. J. Lepr, 40:211, 1972.

REYES, A. Modification a la tecnica de Fite- Faraco para la coloracion de bacilos ácido alcool-resistentes en cortes de tejidos. Dermatologia, México, 7:138-42, 1963.

RHODES-JONES, R. A modified technlque for staining leprosy bacilli in smears. Lepr. Rev., 30:251, 1959. 
SIQUEIRA, L.F. de G. et al. Comportamento tintorial do Mycobacterium leprae. Revisão histórica. Rev. Saúde puibl., S. Paulo, 17:297-315, 1983.

RIDLEY M.J. \& RIDLEY, D.S. Stain techniques and the morphology of Mycobacterium leprae. Lepr. Rev. $42: 88-95,1971$.

RODRIGUEZ, J.; MALABY, E. \& TOLENTINO, J.C. Formas gram-positivas do $M$. leprae de lesões lepróticas bacteriologicamente negativas para organismos ácido-resistentes. Rev. bras. Leprol. 1:111-21, 1933.

RODRIGUEZ, L.L. Coloracion del bacilo de Hansen. Rev. Med. trop. Parasit. Bact. clin. Labor., 8(1):13-4, 1942.

ROTBERG, A. \& BECHELLI, L.M. Etiopatogenia e anatomia patológica. In: Serviço Nacional da Lepra. Tratado de leprologia. Río de Janeíro, 1944. v. 2.

RUDEL, O. Zur farbung der leprabazillen. $Z$ bl. F. Bakt., 107(617): 357, 1928. In: Derm. Wschr., $87(39 \mathrm{~b}): 1.528,1928$. [resumo]

SAMUEL, K.C. \& CHATTERJEE, S.N. Mod1fication of Fite - Faraco staining for acid-fast bacilli. Ind. J. Path. Bact., $14: 107-9,1971$

SANCHEZ, J. Staining of Mycobacterium leprae by the Rio-Hortega silver method in frozen and paraffin sections, Int. $J$. Lepr., 21:331-4, 1953.

SATO, S. \& MAYAMA, A. St:dy on the so-called boil - fastness (resistance of staining against boiling) of leprosy bacilli. Soi. Rep. Res. Inst. Tohoku Univ., Ser. C, 2(1) :21-4, 1950

SERIAL, A. El metodo de Ziehl-Neelsen en los cortes histológicos. Rev. méd. Rosario, $41(1 / 3): 26-8,1951$.

SERIt, C. Laboratory work in leprosy. In: National Leprosy Conference of Ethiopia, 2nd, Addis Ababa, 1961. Report. Addis Ababa, 1962. p. 75 .

SHEPARD, C.C. The nasal excretion of Mycobacterium leprae in Ieprosy. Int. J. Lepr., 30:10-8, 1962.

SHIMIZU, F. Pathohistological findings of peripheral nerves addected by lepra bacilli as examined under the fluorescent microscopical apparatus (Yasaki). $L a$ Lépro, 22(1):43, 1953

SILVA, C. Etiologia. In: Manual de Leprologia. Rio de Janeiro, Serviço Nacional de Lepra, 1960. p. 30-6.
SILVA Jr., M. Miscelanea de assuntos de interesse prático para o sanitarista. IV Diagnóstico da lepra no laboratório. Rev. Hig. Saúde públ., .7(1/2):71-140, 1949.

SMITHWICK, R.W. \& DAVID, H.L. Acridine-orange as a fluorescent counterstain with auramine acid-fast stain. Tuberole, $52: 226-31$, 1971.

SPADA, C. Sulla colorazione vitale del bacilli della lepra col blu di metilene con presentazione di preparati istologici. Boll. Sez. Reg. Brescia, 3:389, 1937.

SUTTER, E. \& ROULET, E.L. Staining Mycobacterium leprae in paraffin sections by the Gomori methanamine silver method. Stain Technol., 40(2):49-51, 1965.

TILDEN, I.I. \& TANAKA, M. Fite's fuchsin-formaldehyde method for acid-fast bacilli applied to frozen section. Amer. $J$. clin. Path. Techn Sect., 9:95-7, 1945.

TORRES, D.M.G. Técnica bacteriológica. In: Torres, D.M.G. Técnica de laboratorio. $3^{a}$ ed. Rio de Janeiro, Editora Scientifica, 1944. p. 295-300.

UNNA, P.G. Eine neue farbemethode fur lepra-und tuberkelbazillen. Mh. prakt. Derm. $12: 477,1891$

UNNA, P.G. Die untercheidung lebender und foter leprabazillen durch doppelfarbung. Mh. prakt. Derm., 51:89, 1910 .

VAN BREUSEGHEM, R. \& MOULES, E. Pratique de la coloration du bacille de Hansen dans les frottis. Ann. Soc. belge Méd. trop., $17: 137-9,1937$.

VEGAS, M. \& ESPIN, J. Aspectos microscópicos de la lepra. I - Coloracion del bacilo de Hansen (proceder combinado de Baumgarten-Biot). Rev. Sanid. Asist. soc., 8:627-34, 1943

VERSARI, A. Contributo alla colorazione del bacillo di Hansen. Rif. med., 40:938-9, 1923.

VESTAL, A.L. Procedures for the isolation and identification of Mycobacteria. Washington, D.C., U.S. Depart. of Health, Education and Welfare. Public Health Service, 1969. 
SIQUEIRA, L.F. de G. et al. Comportamento tintorial do Mycobacterium leprae. Revisão histórica.

Rev. Saúde públ., S. Paulo, 17:297-315, 1983.

VIEIRA, I.R. Comentários sobre os eleitos das sulfonas nas estruturas da lepra. Arch. mineir. Leprol., 9:227-33, 1949.

VIOLA, G. Bacillo della lebbra. In: Viola, G. Trattato di semeiotica. Milano, Casa Editrice Dottor Francesco Vallardi, 1933. v. 2, p. 726.

VON HAFBLERT, T. \& MURRAY, J.F. Fluorescence microscopy as a routhine method for the detection of $M$. tuberculosis and M. leprae. South Afr. med, J., 28(3):45-8, 1954.

WADE, H.W. The variable partial solubility of basic fuchsin in alcool. $J$. Lab. clin. Med., 13:1.052, 1928.

WADE, H.W. The effects of staining technique on the morphology of the leprosy baclllus in smears. In: Congresso Internacional de la Lepra, 5\%, Habana, 1948. Memória. Habana, 1949. p. 512-16.

WADE, H.W. Demonstration of acid-fast bacilli in tissue sections. Amer. J. Path., 28:157-70, 1950 .

WADE, H.W. Notes on the carbowax method of making tissue sections. Stain Technol., 27:71-9, 1952. In: Int. J. Lepr., 20:415, 1952. [resumo]

WADE, H.W. A modification of the Fite-formaldehyde (Fite I) method for staining acid-fast bacilli in paraffin sections. Stain Technol., 32:287-92, 1.957.

WADE, H.W. Lepromin vs purified baclllus suspension. I - Preparation of a purified bacillus suspension (with a note on nile-blue staining of smears). Int. $J$. Lepr., $30: 19-26,1962$ a.

WADE, H.W. Zenker va formalin fixation for the histopathology of leprosy tissues and other desirable features of technique. Int. J. Lepr., 30:477-88, $1962 \mathrm{~b}$.

WENGER, F. Leprosy widespread tumor-like tuberculosis. Arch. Path., 32:112-6, 1941.
WHEELER, E.A. Practical notes on technique for use in preparing sections from biopsies of the skin for histological examinations. In: Cochrane, R.G. \& Daney, T.F. Leprosy in theory and practice, 2nd ed. Bristol, John Wright, 1964. p. 626-31.

WHFELER, E.A.; HAMILTON, E.G. \& HAKMAN, D.J. An improved technique for the hlstopathological diagnosis and classification of leprosy. Lepr. Rev., 86:37-9, 1965.

WHEELER, P.R. \& DRAPER, P. Soluble blue as a counterstain in the Ziehl-Neelsen procedure. Int. J. Lepr., 48:15-7, 1980.

WILKINSON, F.F. Modificacion a la tecnica de Ziehl-Neelsen en las baclloscopias de los enfermos de la lepra tratados con sulfonas. Int. J. Lepr., 19:195-8, 1951.

WILSON, R.A.J. Lillie-Gram stain for bacteria and Flexner stain for lepra bacilli in paraffln section. Amer. J. clin. Path. Techn. Sect., $17: 78-80,1947$.

YASUMOTO, K. Supplemental studies on the morphology and staining properties of acid-fast bacllli. La Lepro, 22:1-85, 1953.

ZABARY-SIMON, P. Métodos de coloraçăo metacromática do Mycobacterium leprae. Rev. bras. Leprol., 15:25-7, 1947.

ZANETTI, V. Coloration en série du bacllle de Hansen et depistage des lepreux baclllaires. Ann. Soc. belge Med. trop., $27: 179-86,1947$.

ZINSSER, H. \& RUSSELL, F.F. Leprosy baclllus. Morphology and staining. In: Zinsser, H. \& Russel, F.F. A textbook of bacteriologie. 8th ed. New York, Appleton, 1922. p. 465.

Recebido para publicagão em 23/12/1988

Aprovado para publicagdo em 06/04/1983 